\title{
Assessment of knowledge of medicinal plants and their use in tribal region of Jashpur district of Chhattisgarh, India
}

\author{
V. K. Painkra ${ }^{1}$, M. K. Jhariya ${ }^{2}$ and A. Raj ${ }^{1}$ \\ ${ }^{1}$ College of Agriculture, Indira Gandhi Krishi Vishwavidyalaya, Raipur-492012 (C.G.), INDIA \\ ${ }^{2}$ Department of Farm Forestry, Sarguja University, Ambikapur-497001 (C.G.), INDIA \\ *Corresponding author E-mail: manu9589@gmail.com
}

Received: January 14, 2015; Revised received: April 20, 2015; Accepted: May 29, 2015

\begin{abstract}
The present study was conducted to assess the knowledge of medicinal plants and their use in tribal region of Jashpur district of Chhattisgarh. Under the socio-economic profile, farmers of middle age (36-55 yrs) people showed the maximum percentage $(78 \%)$ distribution and frequency, 50 per cent of respondents belonged to primary to middle school level of education and 63 per cent of respondents were having medium size of family (5 to 8 members). A total number of 50 medicinal plant species belonging to 29 families were recorded, in which Euphorbiaceae registered as the largest family with 4 plant species (8\%). Shrub showed their maximum presence (34\%) followed by tree (32\%), herb (20\%) and climber $(14 \%)$. As per knowledge of respondents about medicinal plants Haldi and Bhui-neem is mostly use as medicinal purpose as $5.2 \%(n=40)$ followed by Harra, Munga, Karanj and Hadjod (3.9\% each). This information through respondent (tribals) showed very diverse nature of medicinal flora, their usage in healing purpose with socioeconomic/ living standard upliftment. Therefore, it is needful aspect of conserving these biological resources for sustainable ecosystem.
\end{abstract}

Keywords: Biological resource, Ecosystem flora, Medicinal plants

\section{INTRODUCTION}

Medicinal plants play an important role in supporting health care system in India. According to WHO estimate, $80 \%$ of population in developing countries relies on traditional medicine (Bhandary and Chandrashekhar, 2002). In India with more than 75\% of the population residing in rural areas (Anonymous, 1991) close to the natural resources, have rich traditions of utilizing medicinal plants existed among indigenous peoples for ages. Approximately 3000 plants species are known to have medicinal properties in India (Prakasha et al., 2010). It is estimated that $40 \%$ of the world populations depends directly on plant based medicine for their health care (WHO, 2003).

India is a rich diversity centre of medicinal and aromatic plants. Around 45,000 plant species nearly 15,000 plant species are used for their specific medicinal value that shows the remarkable diverse nature of plant species. Documentation is needful aspect for sustain utilization and conservation of medicinal plants (Patel, 2012). According to Raj and Toppo, (2014) , plant diversity assessment and documentation are the first step ahead before the next step of conservation of these biological resources. Assessments of this diverse composition with knowledge about their medicinal properties are very essential for survival of tribal areas people, still live with much dependence on plants. Chhattisgarh is rich in forest resources; about $44 \%$ of the total area of the state is under forest cover. Sal, teak, bamboo, saja etc are major woody perennial tree species found in large number. Among these woody perennial tree species herb and shrub plants are also diversified. Jashpur is one such area in Chhattisgarh, where tribal people live with nature in total harmony. They know the importance of plants and forests for their survival, hence practicing sustainable use of plant resource. This study was conducted to document the medicinal plants with their knowledge uses among the different tribal communities of Jashpur district of Chhattisgarh.

\section{MATERIALS AND METHODS}

The present study was conducted during 2013-2014 in the Jashpur district of Chhattisgarh state (northern

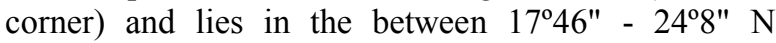
latitude and $80^{\circ} 15^{\prime \prime}-84^{\circ} 24^{\prime \prime}$ E longitude. The upper ghat is an extension plateau covering 1384 sq. Km. Which is about $1200 \mathrm{~m}$ above sea level and is covered with the dense forest. The climate of the area is tropical and annual rainfall is $1885.1 \mathrm{~mm}$. The total forest area of Jashpur is $2752.28 \mathrm{sq}$. km. which constitutes $51.54 \%$ of the total area of the district.

District was selected purposively, because Jashpur district is mostly dominated by the tribal's people and 
maximum area covered by forest. Here people use medical plants as traditional knowledge. Two blocks namely Bagicha and Pharsabahar from district and two villages from each block were selected at randomly. Ten tribal peoples who are different community groups (Kanwar, Oraon, Korva, Gond) from each village were taken randomly, thus a total of forty tribal people as respondent were included in the study sample.

Key informants were identified after preliminary discussion with the people. Information on ethnobotanical uses of the plants was collected by interviewing key informants of the community using a questionnaire having questions related to socio-profile viz., name of village, name of informants, age of informants, cast, education and questions about medicinal plants viz. local name, habit, use of plant, part used etc. The species were observed and identified with the help of local of villages and tribals people. The confirmation of the species is carried out with the help of flora of Chhattisgarh and Madhya Pradesh and other related literature (Hooker's, 1875; Sharma, 2003; De, 2005; Pullaiah, 2006; Trivedi, 2006). Finally, plants were documented by following their botanical name, habits, local name, parts use and uses of the individual plants.

\section{RESULTS AND DISCUSSION}

Socio-economic profile of respondents: Jashpur district of Chhattisgarh is mainly inhabited by different tribal communities whose main occupation is agriculture and collection of forest products. The socio economic data of the proposed study will be useful for the Government and non- Government bodies for the improvement of the condition of the tribals in Jashpur. Age of respondents : In respect to age of respondents, data compiled in table 1 shows that majority $(78.00 \%)$ of respondents belongs to middle age group ( 36 to 55 years), followed by 12 per cent respondents belongs to young age group (up to 35 years), whereas 10 per cent respondents belongs to old age group (More than 55 years), the findings indicated that the majority of knowledge about medicinal plants in study area belonged to middle age groups, followed by young age group. This reflected that young and old people had not much knowledge about medicinal plants.

Table 1. Distribution of respondents according to their age $(\mathrm{n}=40)$.

\begin{tabular}{clc}
\hline S. N. & Age category & Frequency \\
\hline 1. & Young (up to 35 years) & 5 \\
2. & Middle (36 to 55 years) & 31 \\
3. & Old ( More than 55 years) & 4 \\
\hline & Total & 40 \\
\hline
\end{tabular}

Education level of respondents: Regarding education level of respondents, table 2 depicts that about 50 per cent of respondents belongs primary to middle school education level, followed by 18 per cent of respondents found high school level of education, 15 per cent of respondents gained higher secondary level of education, 12 per cent of respondents were illiterate and only 5 per cent of respondents gained college level of education.

Table 2. Distribution of respondents according to their education level $(n=40)$.

\begin{tabular}{lllc}
\hline S. N. & Education & Class & Frequency \\
\hline 1. & Illiterate & 00 & 5 \\
2. & Primary school & $1^{\text {st }}$ to $5^{\text {th }}$ & 11 \\
3. & Middle school & $6^{\text {th }}$ to $8^{\text {th }}$ & 9 \\
4. & High school & $9^{\text {th }}$ to $10^{\text {th }}$ & 7 \\
5. & Higher & $11^{\text {th }}$ to & 6 \\
6. & Secondary & $12^{\text {th }}$ & 2 \\
\hline Total & & Graduate & 40 \\
\hline
\end{tabular}

Family size of respondents: The data regarding family size (Table 3 ) indicated that 63 per cent of respondents were having medium size of family ( 5 to 8 members), followed by 27 per cent respondents had small family size (up to 4 members) and only 10 per cent of respondents had large size of family (Above 8 members).

Knowledge of respondents about medicinal plants: Knowledge of tribal/farmers about medicinal plants is often exclusive to the specific communities and linked to the local flora. 50 medicinal plant species with varied families (29) are recorded by assessment of tribal's knowledge and their medicinal usage comprising different habit viz., tree, shrubs, herbs, climber and tuber. This diversity shows the variability among flora and it is essential to get knowledge about the plant species for medicinal purposes. According to given table 4, Haldi and Bhui-neem is mostly using as medicinal purpose as $5.2 \%$ followed by Harra, Munga, Karanj and Hadjod (3.9\% each). Ashwagandha, Ghritkumari, Bargad, Mahua, Bahera, Muli, Rohini,

Table 3. Distribution of respondents according to their size of family $(n=40)$.

\begin{tabular}{clc}
\hline S.N. & Size of family & Frequency \\
\hline 1. & Small (up to 4 members) & 11 \\
2. & Medium (5 to 8 members) & 25 \\
3. & Large (Above 8 members) & 4 \\
\hline & Total & 40 \\
\hline
\end{tabular}


Table 4. Knowledge of respondents about medicinal plants.

\begin{tabular}{|c|c|c|c|c|}
\hline Knowledge of plant & Family & Habit & Frequency & Percentage \\
\hline Ashwagandha & Solanaceae & Shrub & 1 & 1.3 \\
\hline Ghrit kumarai & Liliaceae & Shrub & 2 & 2.6 \\
\hline Bael & Rutaceae & Tree & 2 & 2.6 \\
\hline Bargad & Moraceae & Tree & 1 & 1.3 \\
\hline Aam & Anacardiaceae & Tree & 2 & 2.6 \\
\hline Mahua & Sapotaceae & Tree & 1 & 1.3 \\
\hline Meda & Lauraceae & Tree & 1 & 1.3 \\
\hline Harra & Combretaceae & Tree & 3 & 3.9 \\
\hline Bahera & Combretaceae & Tree & 1 & 1.3 \\
\hline Aonla & Euphorbiaceae & Tree & 2 & 2.6 \\
\hline Munga & Moringaceae & Tree & 3 & 3.9 \\
\hline Pakad & Moraceae & Tree & 1 & 1.3 \\
\hline Kela (Banana) & Musaceae & Herb & 2 & 2.6 \\
\hline Bhui-neem & Acanthaceae & Shrub & 4 & 5.2 \\
\hline Amrud & Myrtaceae & Tree & 2 & 2.6 \\
\hline Bariyari & Malvaceae & Shrub & 1 & 1.3 \\
\hline Beng sag & Mackinlayaceae & Shrub & 2 & 2.6 \\
\hline Karanj & Fabaceae & Tree & 3 & 3.9 \\
\hline Shatavari & Liliaceae & Climber & 1 & 1.3 \\
\hline Safed musli & Liliaceae & Shrub & 1 & 1.3 \\
\hline Kachri & Zingiberaceae & Climber & 1 & 1.3 \\
\hline Hadjod & Vitaceae & Climber & 3 & 3.9 \\
\hline Minjur chundi & Asteraceae & Climber & 1 & 1.3 \\
\hline Parhi & Menispermaceae & Climber & 2 & 2.6 \\
\hline Sattar kowa (Sahtut) & Moraceae & Climber & 1 & 1.3 \\
\hline Raksha & Acanthaceae & Herb & 1 & 1.3 \\
\hline Aakand (aok) & Asclepiadaceae & Shrub & 1 & 1.3 \\
\hline Tulsi & Labiatae & Shrub & 2 & 2.6 \\
\hline Sapota & Sapotaceae & Tree & 1 & 1.3 \\
\hline Gokul kata (satyanashi) & Papaveraceae & Shrub & 1 & 1.3 \\
\hline Mirch & Solanaceae & Shrub & 2 & 2.6 \\
\hline Haldi & Zingiberaceae & Herb & 4 & 5.2 \\
\hline Muli & Brassicaceae & Herb & 1 & 1.3 \\
\hline Rohini & Euphorbiaceae & Tree & 1 & 1.3 \\
\hline Semal & Malvaceae & Tree & 1 & 1.3 Contd \\
\hline
\end{tabular}


Table 4. Contd...

\begin{tabular}{|c|c|c|c|c|}
\hline Mustard & Brassicaceae & Shrub & 1 & 1.3 \\
\hline Dub ghas & Gramineae & Herb & 2 & 2.6 \\
\hline Chirchitti & Amaranthaceae & Herb & 2 & 2.6 \\
\hline Sadabahar & Apocynaceae & Herb & 1 & 1.3 \\
\hline Nimbu & Rutaceae & Herb & 1 & 1.3 \\
\hline Jada & Euphorbiaceae & Shrub & 1 & 1.3 \\
\hline Tikhur & Zingiberaceae & Shrub & 1 & 1.3 \\
\hline Chhatiyan & Apocynaceae & Tree & 1 & 1.3 \\
\hline Bhanwar malli & Oleaceae & Shrub & 1 & 1.3 \\
\hline Motha & Gramineae & Herb & 1 & 1.3 \\
\hline Bhuiamla & Euphorbiaceae & Shrub & 1 & 1.3 \\
\hline Karonda & Apocynaceae. & Shrub & 1 & 1.3 \\
\hline Kheera & Cucurbitaceae. & Climber & 1 & 1.3 \\
\hline Lal bhaji & Amaranthaceae & Shrub & 1 & 1.3 \\
\hline Dhatura & Solanaceae & Herb & 1 & 1.3 \\
\hline \multicolumn{3}{|c|}{ Total } & 76 & 100 \\
\hline
\end{tabular}

Table 5. Distribution of medicinal plants as per their habit.

\begin{tabular}{lccc}
\hline S.N. & Habit & Number of plant species & Distribution (\%) \\
\hline 1 & Tree & 16 & 32 \\
2 & Herb & 10 & 20 \\
3 & Shrub & 17 & 34 \\
4 & Climber & 7 & 14 \\
5 & Total & 50 & 100.00 \\
\hline
\end{tabular}

Semal etc are comprises lowest use as medicinal purpose $(1.3 \%$ each).As per habit of medicinal plant (Table 5) shrub are mostly seen as they cover a larger number $(17$ species of $34 \%)$ followed by tree (16 species of $32 \%$ ) and herb (10 species of $20 \%$ ) but climber ( 7 species of $14 \%$ ) are least among all. As per family wise distribution (Table 6) of medicinal plants, most frequent plant families were found in the order of Euphorbiaceae (4 species of $8 \%$ ) > Moraceae, Liliaceae, Solanaceae, Zingiberaceae, Apocynaceae (each 3 species of 6\%) > Rutaceae, Sapotaceae, Combretaceae, Acanthaceae, Malvaceae, Amaranthaceae, Brassicaceae, Gramineae (each 2 species of 4\%) > Anacardiaceae, Lauraceae, Moringaceae, Musaceae, Myrtaceae, Mackinlayaceae, Fabaceae, Vitaceae, Asteraceae, Menispermaceae, Asclepiadaceae, Labiatae, Papaveraceae, Oleaceae, Cucurbitaceae (each 1 species of $2 \%$ ).

Information about medicinal uses of plants (ethnobotany) by tribal people: In Jashpur the tribal's are $65.37 \%$ of the total population. Oraon is one of the major populations amongst all the tribal's found in Jashpur (Tiwari et al., 2014). Apart from health care, medicinal plants are mainly the alternate income generating source of underprivileged communities (Myers, 1991; Lacuna-Richman, 2002). Therefore, this sector helps to improve socio-economic with living standard of rural people/tribes. The details about usage of medicinal plants by tribes viz., Kanwar, Oraon, Korva and Gond with their botanical name, habit and economical usable plant parts are given below in Tables 7-10. As per assessment Kanwar tribe used maximum number (26) of floral species as medicinal purpose followed by Oraon tribe (19), Korva tribe (17) and Gond tribe (14). Haldi and Bhui-neem is mostly used by these four tribes as medicinal purpose.

Choudhary et al. (2011) has worked on ethnobotany focussing on four tribal communities i.e., Bhil, Bhilala, Gond and korku and reported a total of 29 species were used by them for remedies in M.P. A total of 89 
Table 6. Medicinal plant species distribution on the basis of the families.

\begin{tabular}{|c|c|c|c|}
\hline S.N. & Family & Number of species & Percentage distribution \\
\hline 1 & Solanaceae & 3 & 6.0 \\
\hline 2 & Liliaceae & 3 & 6.0 \\
\hline 3 & Rutaceae & 2 & 4.0 \\
\hline 4 & Moraceae & 3 & 6.0 \\
\hline 5 & Anacardiaceae & 1 & 2.0 \\
\hline 6 & Sapotaceae & 2 & 4.0 \\
\hline 7 & Lauraceae & 1 & 2.0 \\
\hline 8 & Combretaceae & 2 & 4.0 \\
\hline 9 & Euphorbiaceae & 4 & 8.0 \\
\hline 10 & Moringaceae & 1 & 2.0 \\
\hline 11 & Musaceae & 1 & 2.0 \\
\hline 12 & Acanthaceae & 2 & 4.0 \\
\hline 13 & Myrtaceae & 1 & 2.0 \\
\hline 14 & Malvaceae & 2 & 4.0 \\
\hline 15 & Fabaceae & 1 & 2.0 \\
\hline 16 & Mackinlayaceae & 1 & 2.0 \\
\hline 17 & Zingiberaceae & 3 & 6.0 \\
\hline 18 & Vitaceae & 1 & 2.0 \\
\hline 19 & Asteraceae & 1 & 2.0 \\
\hline 20 & Menispermaceae & 1 & 2.0 \\
\hline 21 & Asclepiadaceae & 1 & 2.0 \\
\hline 22 & Labiatae & 1 & 2.0 \\
\hline 23 & Papaveraceae & 1 & 2.0 \\
\hline 24 & Brassicaceae & 2 & 4.0 \\
\hline 25 & Gramineae & 2 & 4.0 \\
\hline 26 & Amaranthaceae & 2 & 4.0 \\
\hline 27 & Apocynaceae & 3 & 6.0 \\
\hline 28 & Oleaceae & 1 & 2.0 \\
\hline 29 & Cucurbitaceae. & 1 & 2.0 \\
\hline
\end{tabular}

families to be in use among in Geetham block of Dantewada which support the present investigation.

\section{Conclusion}

The information through respondent (tribals) showed very diverse nature of medicinal flora, their usage in healing purpose with socio-economic/ living standard 
Table 7: Details about usage of medicinal plants by Kanwar tribe.

\begin{tabular}{|c|c|c|c|c|}
\hline Local name & Botanical name & Habit & Part use & Usage \\
\hline Ashwagandha & Withania somnifera & Shrub & Leaf and root & fat control and enhance force \\
\hline Ghritkumari & Aloe vera & Shrub & $\begin{array}{l}\text { Leaf and thick } \\
\text { rasp }\end{array}$ & Skin protection \\
\hline Bael & Aegle mormelos & Tree & Fruit & Clean stomach \\
\hline Bargad & Ficus benghalensis & Tree & Upper root & Weakness \\
\hline Aam & Mangifera indica & Tree & Bark & syphilis, wounds and ulcers \\
\hline Mahua & Madhuca indica & Tree & Root & $\begin{array}{c}\text { Cooking and adulteration of } \\
\text { Ghee }\end{array}$ \\
\hline Meda & Litsea monopetala & Tree & Bark & Swelling \\
\hline Harra & Terminalia chebula & Tree & Bark and fruit & Cough \\
\hline Bahera & Terminalia bellirica & Tree & Fruits & Cough and digestive. \\
\hline Munga & Moringa oleifera & Tree & Leaf/tuber & Blood pressure balance \\
\hline Pakad & Ficus infectoria & Tree & Bark & Dysentery \\
\hline Kela (kacha) & Musa paradisiaca & Herb & Fruit & $\begin{array}{c}\text { Leprosy, fevers and hemor- } \\
\text { rhages }\end{array}$ \\
\hline Bhui-neem & $\begin{array}{l}\text { Andrographis } \\
\text { paniculata }\end{array}$ & Herb & Whole part & Malaria fever \\
\hline Amrud & Psidium guajava & Tree & Newly bud sap & Eye infection \\
\hline Bariyari & Sida acuta & Shrub & Leaf pest & Ring worm \\
\hline $\begin{array}{l}\text { Beng sag, Brahmi } \\
\text { buti }\end{array}$ & Centella asiatica & Shrub & Whole part & Increase hungriness \\
\hline Karanj & Pongamia pinnata & Tree & Oil & Etching \\
\hline Shatavari & Asparagus & Climber & Tuber & Enforcement of power \\
\hline Safed musli & $\begin{array}{l}\text { racemosus } \\
\text { Chlorophytum } \\
\text { Borivilianum }\end{array}$ & Shrub & Tuber & Sexual enforcement \\
\hline Kachri & $\begin{array}{l}\text { Hedychium } \\
\text { spicatum }\end{array}$ & Climber & Tuber & Sexual enforcement \\
\hline Hadjod & $\begin{array}{c}\text { Cissus } \\
\text { quadrangular }\end{array}$ & Climber & Leaf & Bone fracture \\
\hline Minjur chundi & $\begin{array}{l}\text { Elephantopus } \\
\text { scaber }\end{array}$ & Climber & Leaf & Bone fracture \\
\hline Parhi & $\begin{array}{l}\text { Cissampelos } \\
\text { pareira }\end{array}$ & Climber & Root & Anti poisonous \\
\hline $\begin{array}{l}\text { Sattar kowa } \\
\text { (Sahtut) }\end{array}$ & Morus alba & Climber & $\begin{array}{l}\text { Bark, root and } \\
\text { fruit }\end{array}$ & Stomach pain \\
\hline Raksha & $\begin{array}{l}\text { Strobulanthus } \\
\text { heiniyanus }\end{array}$ & Herb & Seed & Stomach pain of animal \\
\hline Aakand (aok) & Calotropis Gigantea & Shrub & $\begin{array}{l}\text { Leaves, root, } \\
\text { bark,latex. }\end{array}$ & Fevers, rheumatism, indigestion \\
\hline
\end{tabular}

upliftment. Thus, the present study underlines the potential of the ethnobotanical research and the need for the documentation of traditional knowledge pertaining to medicinal plant utilizing by the respondent under studied and helpful in different ailments in short duration. The conservation of these resources along with domestication, multiplication, sustainable harvesting is required for future generation and for ecological wellbeing.

\section{ACKNOWLEDGEMENTS}

We are thankful to local respondents for sharing their knowledge with us. 
Table 8. Details about usage of medicinal plants by Oraon tribe.

\begin{tabular}{|c|c|c|c|c|}
\hline Local name & Botanical name & Habit & Part use & Usage \\
\hline Tulsi & Mimosa pudica & Shrub & Leaf & Cold and cough \\
\hline Aam & Mangifera indica & Tree & Fruit juice & Syphilis, wounds, ulcers \\
\hline Munga & Moringa oleifera & Tree & Root, leaf & High blood pressure \\
\hline Sapota & Manilkara zapota & Tree & Leaf & anti-inflammatory \\
\hline Satyanashi & $\begin{array}{l}\text { Argemone } \\
\text { maxicana }\end{array}$ & Shrub & $\begin{array}{l}\text { Roots, leaves } \\
\text { and juice. }\end{array}$ & Leprosy and skin-diseases \\
\hline $\begin{array}{l}\text { Beng sag, Brahmi } \\
\text { buti }\end{array}$ & Centella asiatica & Shrub & Whole part & Increase hungriness \\
\hline Harra & Terminalia chebula & Tree & Fruit & Cough \\
\hline Mirch & Capsicum annum & Shrub & Root & Pain of teeth \\
\hline Hadjod & $\begin{array}{c}\text { Cissus } \\
\text { quadrangular }\end{array}$ & Climber & Whole part & Bone fracture \\
\hline Haldi & Curcuma longa & Herb & Rhizome & Body strain \\
\hline Muli & Raphanus sativus & Herb & Leaf and tuber & Jaundice \\
\hline Rohini & $\begin{array}{c}\text { Mallotus } \\
\text { Philipinensis }\end{array}$ & Tree & Bark & Pain relief \\
\hline Parhi & $\begin{array}{l}\text { Cissampelos } \\
\text { pareira }\end{array}$ & Climber & Root & Fever \\
\hline Bhui-neem & $\begin{array}{l}\text { Andrographis } \\
\text { paniculata }\end{array}$ & Herb & Leaf & Malaria treatment \\
\hline Bhuiamla & Phyllanthus niruri & Shrub & Bark and root & Pain relief \\
\hline Karonda & Carissa carandas & Shrub & Bark and root & Pain relief \\
\hline Bael & Aegle mormelos & Tree & Leaf & Relief in head pain \\
\hline Aonla & Emblica officinalis & Tree & Juice & Asthma and digestion problem \\
\hline Karanj & Pongamia Pinnata & Tree & Seed and branch & $\begin{array}{c}\text { Cough, piles, liver pain and skin } \\
\text { irritation }\end{array}$ \\
\hline
\end{tabular}

Table 9. Detail about usage of medicinal plants by Korva tribe.

\begin{tabular}{|c|c|c|c|c|}
\hline local name & Botanical name & Habit & Part use & Usage \\
\hline Hadjod & Cissus quadrangular & Climber & Leaf & Bone fracture \\
\hline Semal & Bombax ceiba & Tree & Gond & Dysentery \\
\hline Karanj & Pongamia Pinnata & Tree & Oil & Itching \\
\hline Mirch & Capsicum annum & Shrub & Root & Teeth pain \\
\hline Bhui-neem & $\begin{array}{l}\text { Andrographis } \\
\text { paniculata }\end{array}$ & Herb & Rasp of plant & $\begin{array}{c}\text { Malaria and purification of } \\
\text { blood }\end{array}$ \\
\hline Haldi & Curcuma longa & Herb & Tuber & Pain killer \\
\hline Mustard & Brassica compestris & Shrub & Leaves,seeds & $\begin{array}{l}\text { Antimicrobial, skin diseases } \\
\text { and cold }\end{array}$ \\
\hline Dub ghas & $\begin{array}{l}\text { Cynodon } \\
\text { dactylon }\end{array}$ & Herb & Whole part & Increase hungriness \\
\hline Chirchitti & Acaranthus aspera & Herb & Bark & Pain killer \\
\hline Aonla & Emblica officinalis & Tree & Root and leaf & Jaundice disease \\
\hline Chhatiyan tree & Alstonia Scholaris & Tree & Bark and root & Breast/chest pain \\
\hline
\end{tabular}


Table 9. Cont.

\begin{tabular}{lllll}
\hline Chhatiyan tree & Alstonia Scholaris & Tree & Bark and root & Breast/chest pain \\
Bhanwar malli & Nyctanthes arbor-tristis & Shrub & Tuber & Fever \\
Motha & Cyperus rotundus & Herb & Green grass & Ulcer \\
Kela (Kacha) & Musa paradisiaca & Herb & Leaves, roots, fruits & Diarrhea and haemostatic \\
Ghritkumari & Aloe vera & Shrub & Pulp & Fever and cold \\
Kheera & Cucumis sativus & Climber & Fruit & Cure to kidney stone \\
Kacha haldi & Curcuma longa & Herb & Tuber & Pain killer \\
\hline
\end{tabular}

Table 10: Detail about usage of medicinal plants by Gond tribe.

\begin{tabular}{lllll}
\hline Local name & Botanical name & Habit & Part use & Usage \\
\hline Sadabahar & Catharanthus roseus & Herb & Flower and leaf & Diarrhea (dast) \\
Dub ghas & Cynodon dactylon & Herb & 21dub ghas+gud & Increase hungerness \\
Nimbu & Citrus limonum & Tree & Fruits, leaves, bark & Antipyretic, cold and \\
and roots & Plomachic \\
Munga & Moringa oleifera & Tree & Plant water & High blood pressure \\
Amrud & Psidium guajava & Tree & Newly leaf & Stomach pain \\
Jada & Ricinus communis & Shrub & Leaf & Jaundice \\
Bhui-neem & $\begin{array}{l}\text { Andrographis pani- } \\
\text { culata }\end{array}$ & Herb & Whole part & Malaria fever \\
Tulsi patta & Ocimum sanctum & Shrub & Leaf & Fever and cough \\
Tikhur & Curcuma angustifo- & Shrub & Tuber & Stomach problem \\
Haldi & $\begin{array}{l}\text { Curcuma longa } \\
\text { Lal bhaji }\end{array}$ & Herb & Tuber & Ulcer and skin treatment \\
Harra & Alternanthera spp. & Shrub & Whole part & Women fertility and mouth \\
Dhatura & Terminalia chebula & Tree & Fruit & ulcer \\
Chirchitti & Achyranthus aspera & Herb & Whole plant & Cough \\
\hline
\end{tabular}

\section{REFERENCES}

Anonymous (1991). Census of India. Primary Census Abstract, Government of India.

Bhandary, M.J. and Chandrashekhar, K.R. (2002). Glimpses of ethnic herbal medicine of coastal Karnataka. Ethnobotany, 14: 1-12.

Choudhary, M.S., Mishra, N., Sharad Trivedi Upadhyay and Upadhyay, R. (2011). Indigenous knowledge of using medicinal plants in treating skin deceases by Tribal's in Central Narmada valley of Madhya Pradesh (India). Bulletin of Environment, Pharmacology and Life Sciences, 1(1): 60-63.

De, L.C. (2005). Medicinal herbs and flowers. Avishkar publishers, Jaipur, India.

Hooker, J.D. (1875). Flora of British India (Vol. I-VII). L. Reeve and Co. Ltd., England.

Lacuna-Richman, C. (2002). The socioeconomic significance of subsistence nonwood forest products in Leyte, Philippines. Environmental Conservation, 29: 253-262.
Mashih, V., Sahu, P.K. and Singh, M. (2013). Observation on ethnomedicinal herbs of Dantewada, Chhattisgarh, India. IJDDHR, 3(3): 644-648.

Myers, N. (1991). The world's forests and human population: the environmental interconnections. Population and Development Review, 16: 1-15.

Patel, D.K. (2012). Medicinal plants in G.G.V. Campus, Bilaspur, Chhattisgarh in central India. Int. J. Med. Arom. Plant, 2(2): 293-300.

Prakasha, H.M., Krishnappa, M., Krishnamurthy, Y.L. and Poornima, S.V. (2010). Folk medicine of NR Pura Taluk in Chikamaglur district of Karnatka. Indian Journal of Traditional Knowledge, 9(1): 55-60.

Pullaiah, T. (2006). Encyclopedia of world medicinal plants. Regency publication, New Delhi.

Raj, A. and Toppo, P. (2014). Assessment of Floral Diversity in Dhamtari District of Chhattisgarh. Journal of Plant Development Sciences, 6(4): 631-635.

Sharma, R. (2003). Medicinal plants of India-An encyclopedia. Daya publishing house, Delhi, India. 
Shrivastava, S. and Kanungo, V.K. (2013). Ethnobotanical Survey of Surguja District with Special Reference to Plants Used by Uraon Tribe in Treatment of Respiratory Diseases. IJHM, 1(3): 131-134.

Tiwari, P., Kusum, E.M. and Prasad, H. (2014). Contribution of Oraon tribe of Jashpur district in the traditional preparation of medicines. Indian J.Sci.Res. 4 (1): 60-63.

Thakur, B., Verma, S., Karkoon, D. and Shrivastava, R. (2013). Ethenomedicinal plant diversity in Mainpur block, district Gariaband, Chhattisgarh, India. IJIRS, 2 (6): 10-24.

Trivedi, P.C. (2006). Medicinal Plants: Ethnobotanical Approach. Agrobios publication.

WHO (2003). Guidelines for the Assessment of Herbal Medicine Programme on Traditional Medicine. Doc. World Health Organization WHO/TRM/91.4.WHO, Geneva. 